\title{
THE RETINAE OF TWO NORTH AMERICAN TELEOSTS, WITH SPECIAL REFERENCE TO THEIR TAPETA LUCIDA
}

\author{
GEORGE A. MOORE
}

Department of Zoology, Oklahoma Agricultural and Mechanical College, Stillwater, Okiahoma ${ }^{1}$

\section{TWO FIGURES}

A tapetum lucidum may be described as a reflective surface or layer located behind the visual-cell layer of the retina. Its function is to return through the retina a large proportion of the light which has already passed through it once in the ordinary way, thus increasing materially the stimulation received by the weakly absorptive visual cells, and lowering the threshold of stimulation of the eye as a whole (see Walls, '42). In most instances the tapetum lucidum is created by a modification of the inner layers of the chorioid coat; but in a few animals (most of them, fishes) the tapetum is constituted by the pigment epithelium of the retina itself, the cells of which, in the tapetalized area of the epithelium, are devoid of the usual melanoid pigment (fuscin) or at most are poorly supplied therewith, and contain masses of reflective particles - usually, guanine or some guanine-like cornpound containing calcium.

In 1941 Dr. Gordon L. Walls (now of the Bausch and Lomb Optical Company) suggested to the writer that Stizostedion Rafinesque probably possesses a tapetum lucidum of the retinal type since the fishes of this percid genus, pikeperches, are close relatives of Sander lucioperca (Linnaeus) (= Lucioperca sandra Cuvier and Valenciennes), in the pigment epithelial cells of which the presence of light-reflecting guanine has long been known. Walls also intimated that a similar condition might be found in Hiodon tergisus LeSueur. Accordingly, when properly fixed eyes were made available, sagittal and tangential sections were eut at $5 \mu$ by the hot colloidin method of Walls ('32). Some sections were stained with Mallory's triple connective tissue

\footnotetext{
IA contribution from the Museum of Zoology of the University of Miehigan and (no. 114) the Department of Zoology of the Oklahoma Agricultural and Mechanical College - a portion of a doctoral dissertation prepared under the direction of Dr. Carl L. Hubbs, to whom the writer is greatly indebted. Thanks are also due to Dr. Gordon L. Walls for valuable suggestions, Dr. W. Frank Blair for supplying the Stizostedion material, and Mr. Milton B. Trautman for the eyes of Hiodon.
} 
stain and others with iron hematoxylin and phloxine. The Stizostedion eyes had been fixed in Zenker's fluid and the Hiodon material in Kolmer's and Perenyi's fluids.

THE RETINA OF STIZOSTEDION V. VITREUM (MITCHILL)

The visual cells of the yellow pikeperch consist of exceedingly large double and somewhat smaller single cones, and very small, numerous rods (fig. $1, A$ and $B$; see also Walls, ' 42 , fig. 170c) which lie in bundles, in small spaces between the pigment epithelial cells. As in other teleost fishes, the cone myoids contract and the rod myoids elongate under the influence of light. Consequently, in the light-adapted eyes available, the cones are closely packed against the external limiting membrane and their greatly enlongated nuclei often project outward through it. In this position the cones form a mosaic pattern much like that of the related genus Perca Linnaeus (Eigenmann and Schafer, '00), with the twin cones at the corners in a continuum of squares and with alternate squares each having a single cone at the center. A ratio of two twin cones to one single cone is thus apparent. Eigenmann and Schafer did not mention a ratio, but their diagram indicates 1:1 for Perca. The rod myoids occupy the small interstices between the cones and do not form a mosaic pattern. They are omitted from $\mathrm{C}$ in figure 1 , where they would show only as tiny dots.

The cone outer segments, being large, show their spiral myeloidal filaments (red in Mallory) very distinctly; but the rod outer segments are so small that no details of structure are visible. The cone ellipsoids are composed of numerous large granular bodies, which are bright red in Mallory's stain. The rod outer segments are yellowish-red and the rod ellipsoids are purple.

Since the number of rods is very great and the number of bipolar and ganglion cells is very small, the degree of summation of visual cells in optic nerve fibers must be high. Correspondingly, the outer nuclear layer is very thick ( $33 \mu$; about nine rows) and the inner nuclear layer is relatively thin (about four rows). The greater part of the thickness of the inner nuclear layer is taken up by the enormous horizontal cells, $64 \mu(62-66 \mu)$ wide and $16 \mu(14-18 \mu)$ thick. The clear and distinct nuclei of these cells are interesting in comparison with the indistinct nuclei of the corresponding cells in Hiodon, discussed below. The inner plexiform layer is relatively thick and is pierced frequently by the very heavy Müller fibers.

The pigment epithelial cells are hexagonal in cross section at their bases, where they are tightly fitted together like tiles, and extend 

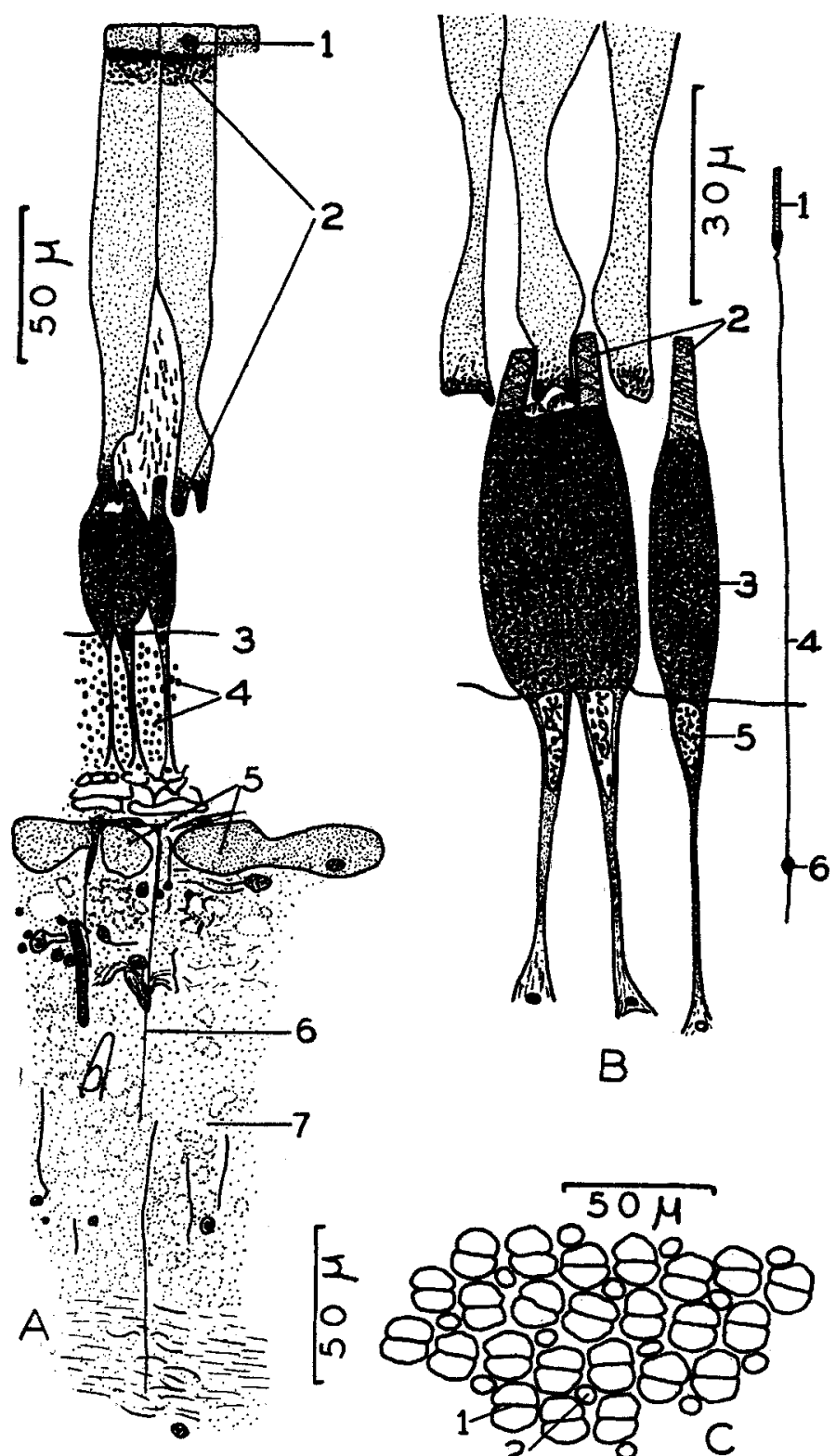

All figures were drawn with the aid of a camera lucida.

Fig. 1 The retina of Stizostedion v, vitreum. A. Sketch of a vertieal section of the retina. The fine dots in the pigment opithelial cells represent guanine; the coarse dots fuscin.
1. nucleus of pigment epithelial cell
5. horizontal cells
2. fuscin granules
6. Müller fiber
3. external limiting membrane
7. inner plexiform layer

B. A twin cone, a single cone, and a rod.
1. rod outer segment
3. cone ellipsoid
2. cone outer segment
4. rod myoid
5. cone nucleus
6. rod nucleus

C. Cross section through the ellipsoids of the cones illustrating the mosaic pattern. 1. twin cone; 2 , eingle cone 
inward to fit over and between the cone outer segments. The pigment cells are constricted near their distal ends where spaces thus formed furnish room for the rod bouquets.

The very large pigment epithelial cells (about $123 \mu$ long) are almost completely filled with guanine. They contain very little fuscin, which is concentrated (in light-adapted material) in the proximal and distal ends of the cells with the greater quantity in the distal portions.

In some respects the tapetum lucidum of Stizostedion v. vitreum is unlike that of Sander lucioperca as reported by Wunder ('30). There are marked differences in the distribution in the retina of the two pigments, guanine and fuscin. In Sander lucioperca the tapetum lucidum forms an ovoid band with its long axis in a horizontal position in the fundus. Progressing from this heavily guaninized area out toward the ora serrata, Wunder found first a fairly broad zone which had some guanine and some fuscin, then a narrow outer zone where there was no guanine and much more fuscin. In Stizostedion v. vitreum the pigment epithelial cells, regardless of their position in the retina, are practically filled with coarse guanine crystals. However, there is a greater quantity of fuscin near the ora serrata than in the fundus (where there is very little). Thus the effective area of the tapetum would seem to be relatively much greater in the Stizostedion than in the Sander. These distinctions in retinal characters confirm the view of American ichthyologists that Stizostedion should be recognized as generically distinct from the Old World genus Sander (Lucioperca).

A similar extensive distribution of guanine in the retina has been reported by McEwan ('38) for the Mormyridae and Elopidae.

\section{THE RETINA OF HIODON TERGISUS (LeSueur)}

There are no cones in the retina of Hiodon, though a first glance at the outer nuclear layer suggests that the visual cells are of more than one type, since the nuclei vary in size and in density, and some protrude through the external limiting membrane (like the cone nuclei of other teleosts) while others do not. Pure-rod teleost retinae are supposedly restricted to deep-sea forms, except perhaps for the siluroid Clarias batrachus (Linnaeus), in poorly fixed eyes of which Verrier ('27) failed to find cones.

The rods of Hiodon form bundles which lie between the pigment epithelial cells in a definite mosaic fashion (fig. 2). Their myoids are heavy at the level of the external limiting membrane and for some distance above, then suddenly become slender. There is thus an interesting superficial similarity to the visual-cell bundles of a mormyrid. 
Petrocephalus stuhlmanni Boulenger, as illustrated by McEwan ('38). In Petrocephalus, however, it is the whole of the cone inner segment which is responsible for the flaring of the base of each bundle of visual cells - the cone outer segments are thread-like and are intermingled
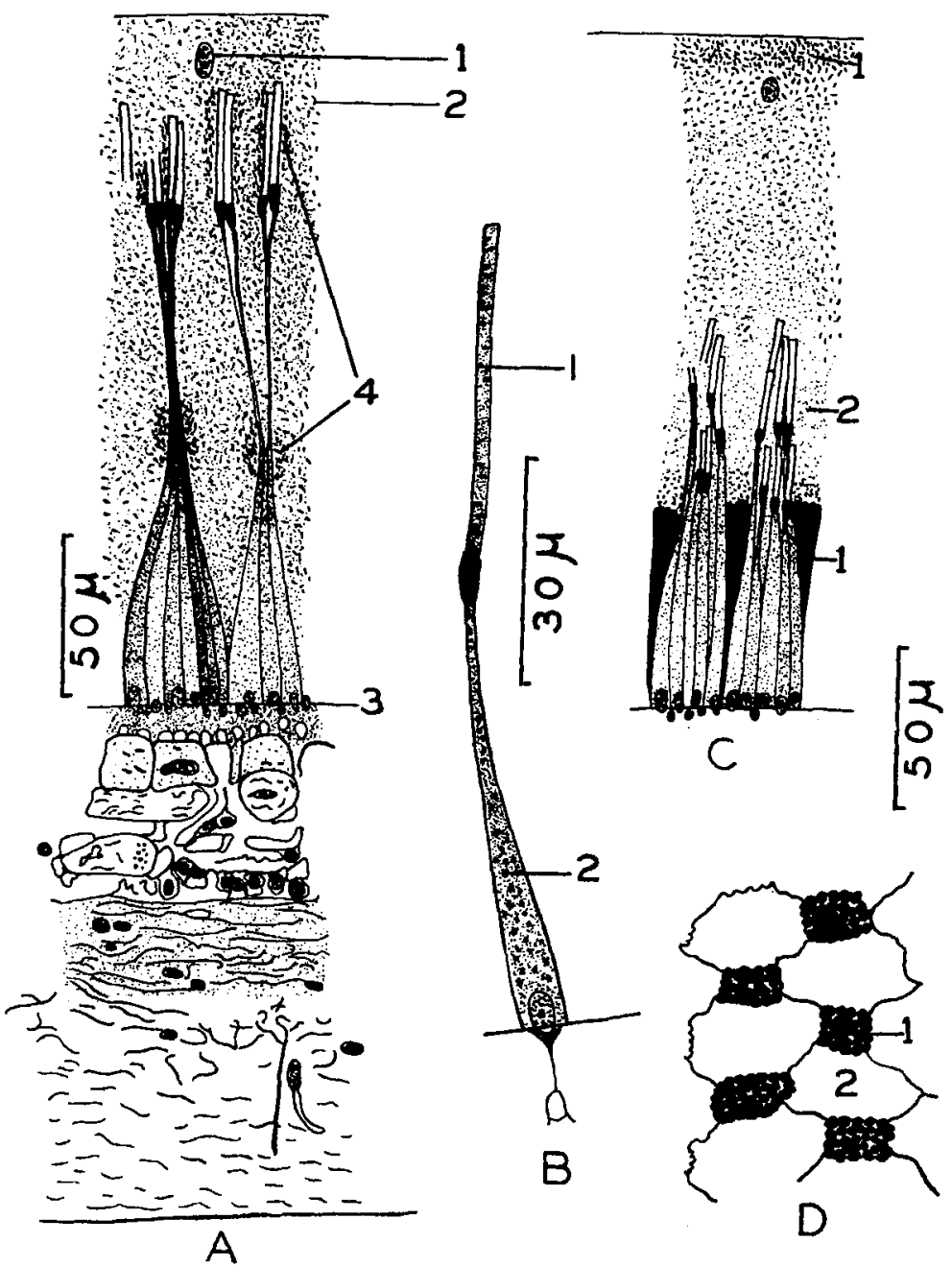

Fig. 2 The retina of Hiodon tergisus.

A. Sketch of a vertical section of the retina in a light-adapted eye.
1. nucleus of pigment epithelial cell
3. external limiting membrane
2. fuscin granule
4. areas of fuscin concentration

B. Rod. 1. outer segment; 2, myoid.

C. Visual cells and pigment epithelium in a dark-adapted eye. 1. fuscin; 2. guanine.

D. A cross section in the region of rod ellipsoids showing their arrangement in bundles between the pigment epithelial cells. 1. rod bundle; 2. pigment epithelial process. 
with the tiny rod bodies to form the slender terminal tuft on each visual-cell bundle.

The rod myoids in Hiodon elongate under the influence of light, but differ from those of most other teleosts in that their basal portions keep about the same diameter as in the contracted state. In a lightadapted retina the base of the myoid is $4.3 \mu(3.6-4.9 \mu)$ in diameter, while in a dark-adapted retina it measures $4.7 \mu(3.8-5.4 \mu)$. The constriction produced in the rod bundle by the sudden reduction of myoid diameter probably has some significance for the shielding of the sensitive rods from bright light, for the fuscin tends to form concentrations at these constrictions in light-adaptation. The rod bodies then lie beyond these protective clouds of pigment, on the side away from the incoming light. In light-adaptation there are concentrations of fuscin alongside the rod outer segments as well, as in teleosts and amphibians generally.

Dark adaptation produces a very evident shortening of the slender portions of the myoids, and a consequent thickening where the constriction is located in the light-adapted rod bundle (compare $\mathrm{A}$ and $\mathrm{C}$ in fig. 2). The fuscin forms a mild concentration in the bases of the pigment cells, but no dense band of pigment forms here. Instead, in great contradistinction to all other known vertebrates which have been demonstrated to possess migratory retinal pigment, the preponderant mass of the pigment in the dark-adapted Hiodon retina lies in the tips of the pigment-cell processes. On comparing light- and dark-adapted retinae of Hiodon, one's first thought is that the directions of migration are opposite to those of other vertebrates - or that the labels on the material have been exchanged. However, the conical masses of pigment which form in the dark-adapted retina do not in the least interfere with the stimulation of the rods, for practically all of the ligbt which reaches the external limiting membrane is free to enter the rod myoids, and would be funneled (by total internal reflection) into the photosensitive bodies of the rods. In order to clarify the layer of reflective particles so that it can serve as an efficient tapetum lucidum, Hiodon has chosen to get the fuscin granules out of the way by aggregating them in the "wrong" end of the pigment cell; but no harm is done thereby. The writer can offer no explanation of the evolution of this unorthodox phenomenon.

In tangential sections the pigment epithelial cell membranes are conspicuous and are tightly pressed against the rod bundles, which are arranged in staggered rows ( $D$, fig. 2$)$. There is a striking resemblance 
to MeEwan's ('38) representation of a similar section from Elops saurus Linnaeus.

The reflective pigment of the pigment epithelium differs in some respects from that of Stizostedion. Fresh, unprocessed sections have a bright, silvery appearance when viewed through the microscope, but the brilliance of this sheen is greatly diminished when the sections are passed through Mallory's reagents. It is uncertain whether this is due to differences in the chemical nature of the reflecting substances of the two retinae; but in Stizostedion the guanine crystals are large and remain conspicuous in the finished slide. In Hiodon the particles, whatever they may be, are quite small, and their loss of conspicuousness after mounting in Clarite suggests that they may not be unmodified guanine, but some other probably related substance with higher refractive index.

The horizontal cells are large and regularly exhibit deeply staining fibers. The bipolar and ganglion cells are few in numbers and the Müller fibers are not as conspicuous as those of Stizostedion.

\section{DISCUSSION}

Wunder ('30) found that in Lake Balaton, the largest middle European lake, the most common fishes - Sander lucioperca (Linnaeus), Blicca bjorkna (Linnaeus), and Pelecus cultratus (Linnaeus) - possess guanine in their pigment epithelia. In addition to these common forms, Sander volgensis (Pallas), Abramis brama (Linnaeus), and Acerina cernua (Linnaeus), also found in Lake Balaton, have similar guanine tapeta lucida. Wunder concluded that there is a biological connection between the turbidity of Balaton water and the presence of guanine in the pigment epithelium.

Although Lake Balaton is large in area, it has an average depth of only 3 meters. As a consequence, wave action keeps the silt in constant motion, producing a very turbid condition. Wunder found a tapetum lucidum in 6 of the 37 species known to occur in this lake (ten species were not studied). Those fishes that possess a tapetum are assumed to be more successful in Lake Balaton than are the species without such a structure. In other words, they are pre-adapted to life in weak illumination. The visual activities of the species not provided with tapeta would in all probability be limited to the upper strata of water even on bright days. This fact was appreciated by Walls ('42; $p, 210$ ) and made evident by Higgins ('32), who reported that in the Mississippi River $90 \%$ of the light is eliminated in the first $25 \mathrm{~mm}$. of water. 
Determinations by Ellis ('36) revealed that the "millionth intensity" depth (at which light is reduced to one millionth of its surface intensity) was only $84 \mathrm{~mm}$. in a surface sample of water from the Missouri River at Boonville, Missouri. In contrast, the clearest natural stream studied was the Rio Saltillo in Mexico, in which the millionth intensity depth was 54 meters.

Stizostedion $\nabla$. vitreum ordinarily stays away from the shoals, particularly by day during the summer. The young, when in shallow clear water in the day, usually remain under cover (Hubbs, personal communication). Raney and Lachner ('42) reported that as summer progresses, the young gradually move to deeper water. These workers found that by the first week in August it was necessary to seine in weed beds to capture young specimens, and by August 25th they were rarely in less than 5 feet of water.

It is not possible at present to correlate these movements with eye structure, but it seems likely that it is the development and growing efficiency of the tapetum which causes the pikeperch to retreat to deeper water and to shady places to escape the dazzling rays of the summer sun. The entire pigment epithelium is packed with guanine; and since the cells of this layer are very large, the space afforded for the rods in the light-adapted condition is so meager that many rods are forced to remain close to the external limiting membrane. The possibility of dazzlement is evident. In Sander, on the other hand, there is plenty of room for the elongating rods to aggregate at some distance from the membrane, and between the rods and the membrane the closed-in ranks of the pigment cell processes, each containing considerable fuscin, form a light-stopping shield for the rods and a light-absorptive backing for the cones. Sander is thus far better able than Stizostedion to adapt to bright light without need of fleeing from it. The much smaller area of the Sander tapetum might lead one to expect this, for it implies that Sander is less thoroughly committed to dim-light activity than Stizostedion.

The eyes of the sauger, Stizostedion canadense (Smith), have not been studied. Doan ('41) found a statistically significant positive correlation between the turbiditv of Lake Erie in April and May and the poundage of the commercial catch of saugers 3 years later. $\mathrm{He}$ suggested that food organisms important to young saugers are more abundant near the surface, where the fry feed, in times of high turbidity; that turbid waters might coat the eggs with silt and prevent them from sticking together in large clumps (making them more vulnerable to predators); and that the fry would find more protection 
from enemies in muddy water. After a study of the sauger eye is completed, one other suggestion may be pertinent. The presence of turbid conditions may make it possible for the fry to survive near the surface since they may be better able to make use of visual stimuli in dim light than in bright. It will be interesting to determine whether the sauger has a more highly developed tapetum lucidum than the pikeperch, although at present this seems scarcely possible. Mr. Milton B. Trautman (personal communication) states that S. vitreum in Ohio is chiefly restricted to clear water whereas $\mathbf{S}$. canadense is most abundant in roily water. The Muskingum, a rather clear stream, contains more S. vitreum than canadense while in the Scioto, a turbid stream, the reverse is true.

A moderately dim light seems to be preferred by Hiodon tergisus. According to Hubbs and Lagler ('41) this species frequents the open waters of large lakes and streams, in a region where such waters are often turbid. It is not known to occur in deep water. In Lake Erie it is taken mostly in Sandusky Bay, seldom in clearer parts (Van Oosten, personal communication), and is caught chiefly in seines, which are dragged between 6:00 A. M. and noon, in shallow water in the summer.

The Hiodon retina appears to effect a fairly efficient light-adaptation (i. e., a shielding of the rod outer segments from bright light). This is in contrast to the situation in the Mormyridae, which McEwan ('38) pronounces: " . . incapable of adaptation to bright light and thus their sense of sight cannot be good." The mormyrids thus compare (physiologically) more with Stizostedion, and Hiodon more closely with Sander despite the close relationship between Stizostedion and Sander. It is puzzling that Stizostedion, lacking effective photomechanical changes, has retained a duplex retina (with an unusually high ratio of double to single cones, ordinarily connoting diurnal activity), whereas Hiodon possesses light-adaptive photomechanical changes although it has a pure-rod retina.

From McEwan's work it seems certain that the mormyrid fishes have cones as well as rods, but this cannot be asserted for all of the Elopidae which she studied (and which she found to have retinal peculiarities like those of the Mormyridae). McEwan states that she saw cones in cross sections of the visual-cell bundles of Tarpon (= Megalops), but not in the preparations of Elops (the material of which, however, was poorly fixed). Though she gives the dimensions of Elops cones, her drawings show only rods.

Although it thus seems possible that the Elops retina is actually pure-rod, and that further studies of that genus would reveal it to be 
very closely comparable with Hiodon, the similarities in retinal structure of the Elopidae, Mormyridae, and Hiodontidae can probably all be attributed to convergent evolution. Such a view would harmonize with current concepts of phylogenetic relationships among soft-rayed teleosts. Following the anatomical researches of Ridewood, Regan, and others, these families are now generally placed in distinct suborders. This course is followed in the most recent general classification of fishes, that of Berg ('40).

\section{MAIN CONCLUSIONS}

1. Stizostedion v. vitreum has large twin cones and single cones in $2: 1$ ratio, and very numerous, tiny rods grouped in bouquets between the elongated pigment epithelial cells. The number of visual cells per optic nerve fiber is high.

2. In Stizostedion the pigment epithelial cells are very long and heavy and are packed with guanine, serving as a reflective material to create a retinal tapetum lucidum for the promotion of dim-light vision. There is so little fuscin that its migrations cannot accomplish the occulsion of the tapetum in bright light. The tapetum of Stizostedion thus differs sharply from that of its close relative in Europe, Sander. The tapetum of Sander is relatively smaller in area, implying that Stizostedion is the more thoroughly adapted for dim-light vision. No other American percid is known to have a tapetum.

3. Hiodon tergisus has only rods, which are gathered into tapered bundles alternating with the elongated pigment cells. The rod myoids are thick at their bases, producing a superficial similarity to the retinae of the mormyrid and elopid fishes described by McEwan ('38).

4. The photomechanical changes in Hiodon, in contrast to those of Stizostedion $\nabla$. vitreum, are probably effective in shielding the rods from bright light, since the light-adapted fuscin forms concentrations in appropriate locations. In dark-adaptation, however, the fuscin accumulates chiefly in the tips of the pigment-cell processes instead of in the bases of the cells. In this respect Hiodon contrasts sharply with all other vertebrates in which the eyes have been studied.

5. The pigment epithelium of Hiodon constitutes a retinal tapetum lucidum. Its reflective material is probably a chemical relative of guanine. Hiodon is the first freshwater clupeoid reported to have a retinal tapetum and is the first non-deep-sea teleost (excepting perhaps Clarias batrachus and Elops saurus) known to have a pure-rod retina. 
6. The known habits of Stizostedion and Hiodon seem to be in keeping with the presence of a tapetum lucidum, but further information is needed regarding the habitats of both genera.

7. The superficial retinal similarities of the Hiodontidae and the Mormyridae, and the possibly closer similarities of the Hiodontidae and the Elopidae, are probably attributable to convergent evolution.

\section{LITERATURE OITED}

BERG, L. S. 1940 Classification of fishes, both recent and fossil. Trav. Inst. Zool. Acad. Sei. U. R. S. S., vol. 5, pp. 85-217 (Russian and English texts).

DoAn, K. H. 1941 Relation of sauger catch to turbidity in Lake Erie. Ohio Jour. Sci., vol. 41, pp. 449-452.

EtGENMANN, C. H., AND G. D. SCHAFER 1000 The mosaic of single and twin cones in the retina of fishes. Amer. Nat., vol. 34, pp. 109-118.

Eluss, M. M. 1936 Erosion silt as a factor in aquatic environments. Ecology, vol. 17, pp. $29-42$.

Higarns, E. 1932 Progress in biologieal inquiries. Appendix III. Rep. U. S. Comm. Fish., 1931, pp. 441-569.

HubBs, C. L., aNd K. F. LAGLer 1941 Guide to the fishes of the Great Lakes and tributary waters. Cranbrook Inst. Sei. (Bloomfield Hills, Mieh.), Bull. 18.

McEWAN, M. R. 1938 A comparison of the retina of the mormyrids with that of various other teleosts. Acta Zool., vol. 19, pp. 427-465.

RANEY, E. C., AND E. A. LACHNER 1942 Studies of the summer food, growth and movements of young yellow pike-perch, Stizostedion $\nabla$. vitreum, in Oneida Lake, New York. J. Wildlife Management, vol. 6, pp. 1-16.

VERRIER, M. L. 1927 La structure de l'oeil de Clarias batrachus L. et d'Ameiurus nebulosus LeSueur, ses rapports avee l'habitat et le comportement biologique de ces deux siluridés. Bull. Soe. Zool. France, vol. 52, pp. 581-588.

WaLls, G. L. 1932 The hot celloidin technic for animal tissues. Stain Tech.. rol. 7, pp. 135-145.

1942 The vertebrate eye. Cranbook Inst. Sei. (Bloomfield Hills, Mieh.), Bull. 19.

WUNDER, W. 1930 Bau und Funktion der Netzhaut beim Zander (Lucioperea sandra Cuv. and Val.) und einigen anderen im Balatonsee haüfigen Fischarten. Zeits. f. vergl. Physiol., Bd. 11, S. 749-766. 